\title{
Pengaruh pupuk organik cair kulit buah pisang kepok (Musa paradisiaca L. var. balbisina colla.) terhadap pertumbuhan tanaman bayam (Amaranthus gracilis Desf)
}

\author{
Rana Ashma Nabilah ${ }^{1 *}$, Ambar Pratiwi ${ }^{2}$ \\ Biologi, Fakultas Sains dan Teknologi Terapan, Universitas Ahmad Dahlan \\ Jl. Jendral Ahmad Yani (Ringroad Selatan) Tamanan, Banguntapan, Bantul \\ Daerah Istimewa Yogyakarta 55191 \\ 1x8_ranaashmanabilah@yahoo.com*; 2 ambar@bio.uad.a.id \\ *korespondensi penulis
}

\begin{abstract}
Abstrak
Pisang kepok yang biasa dikonsumsi adalah bagian buahnya, baik secara langsung maupun diolah misalnya menjadi gorengan. Sementara itu bagian kulitnya berakhir sebagai sampah. Hal tersebut apabila dibiarkan begitu saja dapat menyebabkan penumpukan sampah, yang menyebabkan bau tidak sedap. Berdasarkan hal tersebut, salah satu solusi yang dapat dilakukan adalah kulit buah pisang kepok diolah menjadi pupuk organik cair. Kulit buah pisang kepok mengandung unsur makro meliputi N, P, dan K yang dapat mendukung pertumbuhan tanaman. Tujuan dari penelitian ini untuk menentukan pengaruh pupuk organik cair (POC) dan konsentrasi yang optimal terhadap pertumbuhan tanaman bayam (Amaranthus gracilis Desf) meliputi panjang daun, lebar daun, tinggi batang, berat basah, berat kering, dan kadar klorofiL. Variabel bebas penelitian ini meliputi konsentrasi POC kulit buah pisang kepok (Musa paradisiaca L. var. balbisina colla.) $0 \mathrm{~mL} / \mathrm{L}$, $10 \mathrm{~mL} / \mathrm{L}, 20 \mathrm{~mL} / \mathrm{L}, 30 \mathrm{~mL} / \mathrm{L}, 40 \mathrm{~mL} / \mathrm{L}$, dan $50 \mathrm{~mL} / \mathrm{L}$. Variabel terikat adalah pertumbuhan tanaman bayam. Metode yang dilakukan pada penelitian adalah secara eksperimen. Data dianalisis menggunakan analisis variansi (ANAVA) dan dilanjutkan dengan uji Duncan Multiple Range Test (DMRT) pada taraf 5\%. Data dikomputerisasi menggunakan aplikasi SPSS 22. Hasil penelitian menunjukkan bahwa pemberian POC dari kulit buah pisang kepok (Musa paradisiaca L. var. balbisina colla.) berpengaruh baik terhadap serta dapat meningkatkan pertumbuhan tanaman bayam (Amaranthus gracilis Desf) meliputi panjang daun dan lebar daun pada konsentrasi $10 \mathrm{~mL} / \mathrm{L}$ (P1) dan kadar klorofil pada konsentrasi $50 \mathrm{~mL} / \mathrm{L}$ (P5).
\end{abstract}

Kata kunci: Pupuk, kulit, pisang kepok, pertumbuhan tanaman, unsur hara.

\begin{abstract}
Kepok bananas are commonly consumed are part of the fruit, both directly and processed for example into fried foods. Meanwhile the skin ends up as rubbish. This if left unchecked can cause buildup of garbage, which causes unpleasant odors. Based on this, one solution that can be done is the peel of kepok bananas processed into liquid organic fertilizer. Kepok banana peel contains macro nutrient including $\mathrm{N}, \mathrm{P}$, and $\mathrm{K}$ which can support plant growth. The aims of this study was to determine the effect of liquid organic fertilizer (LOF) and optimal concentration on the growth of spinach (Amaranthus gracilis Desf) including leaf length, leaf width, stem height, plant wet wight, plant dry weight, and chlorophyll content. The independent variables of this study include LOF concentrations of kepok banana peel (Musa paradisiaca L. var. balbisina colla.) $0 \mathrm{~mL} / \mathrm{L}, 10 \mathrm{~mL} / \mathrm{L}$, $20 \mathrm{~mL} / \mathrm{L}, 30 \mathrm{~mL} / \mathrm{L}, 40 \mathrm{~mL} / \mathrm{L}$, and $50 \mathrm{~mL} / \mathrm{L}$. The dependent variable is
\end{abstract}


spinach plant growth. The method used in the research is experimentally. Data were analyzed using analysis of variance (ANAVA) and followed by Duncan Multiple Range Test (DMRT) at 5\% level. Data is computerized using the SPSS22 application. The results showed that LOF from the peel of kepok banana had a good effect and could increase the growth of spinach including leaf length and leaf width at a concentration of $10 \mathrm{~mL} / \mathrm{L}(\mathrm{P} 1)$ and chlorophyll content at a concentration of $50 \mathrm{~mL} / \mathrm{L}$ (P5).

Keywords: fertilizer, peel, kepok bananas, growth of plant, nutrient.

\section{PENDAHULUAN}

Pisang merupakan komoditas yang mudah dibudidayakan dan memiliki berbagai macam jenis. Umumnya masyarakat Indonesia dari berbagai kalangan umur maupun status sosial menggemari pisang, karena harganya yang relatif terjangkau. Pisang dapat dikonsumsi secara langsung (segar) ataupun dalam bentuk olahan misalnya digoreng (Rohmah, 2016). Pisang kepok yang biasa dikonsumsi oleh masyarakat hanya bagian daging buahnya yang diolah sebagai gorengan, lalu bagian kulit buahnya dibuang sebagai sampah, sehingga menyebabkan bau tidak sedap jika tidak dikelola dengan benar. Apabila dibiarkan begitu saja kulit pisang kepok dapat menyebabkan penumpukan sampah, yaitu kulit buah pisang kepok (Rambitan dan Mirna, 2013). Berdasarkan hal tersebut, maka diperlukan solusi untuk menangani kulit buah pisang kepok. Salah satu solusi yang dapat dilakukan yakni kulit buah pisang kepok dimanfaatkan dan diolah menjadi bahan yang lebih bermanfaat, misalnya diolah menjadi pupuk organik cair (POC). Pupuk organik cair memiliki kelebihan yakni unsur hara yang dikandung lebih cepat dan mudah diserap oleh akar tanaman (Paradosi dkk, 2014), sedangkan pupuk anorganik memiliki dampak negatif terhadap lingkungan. Berdasarkan hasil penelitian Rahmawati dkk (2017) bahwa pupuk organik cair buah kulit pisang kepok dengan konsentrasi $25 \%$ berpengaruh terhadap pertumbuhan tanaman selada (Lactuca sativa). Unsur yang dikandung oleh kulit buah pisang meliputi unsur makro N, P, dan K. Selain itu juga terkandung unsur mikro meliputi unsur mikro $\mathrm{Ca}, \mathrm{Mg}$, dan $\mathrm{Zn}$ yang berfungsi sebagai kekebalan dan pembuahan pada tanaman (Rambitan dan Mirna, 2013).

Badan Pusat Statistik menyatakan bahwa produktivitas untuk komoditas bayam hijau di Indonesia dari tahun 2016-2017 mengalami penurunan. Tahun 2016 rata-rata produksi bayam hijau mencapai 160.248 ton, sedangkan tahun 2017 menjadi 148.295 ton (Badan Pusat Statistik, 2017). Tujuan dari penelitian ini adalah menentukan pengaruh dan konsentrasi POC pupuk kulit buah pisang kepok (Musa paradisiaca L. var. balbisina colla.) yang dapat meningkatkan pertumbuhan panjang daun, lebar daun dan kadar klorofil daun tanaman 
bayam (Amaranthus gracilis Desf). Tujuan penelitian ini adalah untuk menentukan pengaruh Berdasarkan uraian tersebut untuk mengurangi penggunaan pupuk anorganik dan meningkatkan produktivitas tanaman bayam hijau, maka dapat diupayakan pemanfaatan kulit pisang kepok secara optimal dalam bentuk pupuk organik cair.

\section{METODE}

Penelitian dilaksanakan selama dua bulan, yakni dari bulan Maret sampai dengan bulan Mei 2019. Penanaman bayam hijau serta pengamatan dilakukan di Green house buatan di daerah Kretek, Bantul, Yogyakarta. Penimbangan berat basah dan berat kering dilakukan di Laboratorium Biologi, Universitas Ahmad Dahlan. Uji kadar klorofil dilakukan di Laboratorium Farmasi, Universitas Muhammadiyah Yogyakarta.

\section{Jalannya Penelitian}

Tahap-tahap yang dilakukan pada penelitian adalah sebagai berikut:

\section{Persiapan}

Kulit buah pisang kepok (Musa paradisiaca L. var. balbisina colla.) diambil dari penjual gorengan serta mempersiapkan alat dan bahan untuk pembuatan POC.

\section{Pembuatan Pupuk Organik Cair}

Bagian pangkal dan ujung kulit pisang kepok dipotong, sehingga hanya tersisa kulit buah pisang saja, kemudian dipotong kecil-kecil dengan ukuran kurang lebih $2 \mathrm{~cm}$. Kulit buah pisang yang telah dipotong lalu diblender hingga halus, kulit buah pisang yang telah diblender dimasukkan ke dalam ember plastik, ditambahkan $2 \mathrm{~L}$ air, $50 \mathrm{~g}$ gula pasir, dan 50 mL EM4, lalu diaduk hingga rata dan pH cairan diukur (Rambitan, 2013).

\section{Persiapan Media Tanam}

Tanah yang digunakan pada penelitian ini adalah tanah perkarangan rumah yang dijemur di bawah sinar matahari. Tanah tersebut dimasukkan ke dalam polybag berukuran $25 \times 25 \mathrm{~cm}^{2}$. Tanah yang digunakan sebanyak $2 \mathrm{~kg} /$ polybag.

\section{Penyemaian Biji}

Biji bayam hijau disemai di tanah pekarangan selama 14 hari. Benih yang telah disemai dipilih umur yang sama untuk dipindahkan ke media tanam yang telah disiapkan untuk diadaptasikan selama 3 hari.

\section{Perlakuan}

Tanaman bayam hijau yang telah diadaptasikan selama 3 hari dipindahkan ke media tanam yang telah disiapkan. Pemupukan dilakukan dengan cara disiram dengan konsentrasi 
pupuk organik cair $0 \mathrm{~mL} / \mathrm{L}, 10 \mathrm{~mL} / \mathrm{L}, 20 \mathrm{~mL} / \mathrm{L}, 30 \mathrm{~mL} / \mathrm{L}, 40 \mathrm{~mL} / \mathrm{L}$, dan $50 \mathrm{~mL} / \mathrm{L}$ dengan volume penyiraman $75 \mathrm{~mL} /$ polybag. Perlakuan penyiraman dilakukan pada 0 Minggu Setelah Tanam (0 MST), 1 MST, 2 MST, dan 3 MST.

\section{Perawatan dan Pengamatan}

Perawatan dilakukan dengan cara tanaman disiram satu hari sekali dengan air sebanyak $75 \mathrm{~mL}$ pada pagi hari. Pengamatan dilakukan seminggu sekali dengan parameter yang diukur, yaitu: tinggi batang, panjang daun, lebar daun, berat basah, berat kering, dan kadar klorofil. Parameter lingkungan, yang diukur meliputi suhu dan kelembapan dilakakukan pada 0 MST, 1 MST, 2 MST, 3 MST, dan 4 MST.

\section{Analisis Data}

Data dianalisis menggunakan Analisis Variansi (ANAVA) dengan satu faktorial untuk mengetahui pengaruh perlakuan terhadap variabel yang diamati. Apabila terdapat beda nyata maka dilanjutkan dengan Duncan Multiple Range Test (DMRT) untuk mengetahui perbedaan tiap perlakuan.

\section{HASIL DAN PEMBAHASAN}

Pupuk organik cair adalah larutan hasil fermentasi sisa-sisa tanaman, hewan maupun manusia yang mengandung unsur hara yang dapat mendukung pertumbuhan tanaman. Proses pembuatan pupuk organik cair dibantu oleh mikroorganisme yang mendegradasi bahan organik yang kompleks menjadi lebih sederhana, sehingga mudah untuk diserap oleh akar tanaman. Lama waktu yang dibutuhkan untuk pembuatan pupuk organik cair tergantung dari bahan yang digunakan. Bahan yang digunakan pada penelitian ini adalah kulit buah pisang kepok (Musa paradisiaca L. var. balbisina colla.). Proses fermentasi kulit buah pisang kepok (Musa paradisiaca L. var. balbisina colla.) pada penelitian ini dibutuhkan waktu tiga minggu untuk mencapai titik akhir fermentasi. Menurut Wahyuningsih dan Edy (2013) lama waktu proses fermentasi berbeda-beda berkisar antara 7 sampai 21 hari. Lama waktu fermentasi tergantung oleh bahan yang digunakan, serta aktivitas mikroorganisme. Hasil pengamatan dan analisis pupuk organik cair kulit buah pisang kepok (Musa paradisiaca L. var. balbisina colla.) pada Tabel 1. 
Tabel 1. Hasil pengamatan dan analisis pupuk organik cair kulit buah pisang kepok (Musa paradisiaca L. var. balbisina colla.)

\begin{tabular}{cccc}
\hline No & Parameter & Satuan & Hasil \\
\hline 1. & Suhu & ${ }^{\circ} \mathrm{C}$ & $28^{\circ} \mathrm{C}$ \\
2. & Warna & & $\begin{array}{c}\text { Kuning kecoklatan } \\
\text { Asam }\end{array}$ \\
3. & Bau & & 5,4 \\
4. & $\mathrm{pH}$ awal & & 4,1 \\
5. & $\mathrm{pH}$ akhir & & \\
\multicolumn{1}{c}{ Kadar Unsur } & & 2,96 \\
6. & Karbon (C) & $\%$ & 0,04 \\
7. & Nitrogen (N) & $\%$ & 68,29 \\
8. & Rasio C/N & $\%$ & 0,15 \\
9. & Fosfor (P) & $\%$ & 0,08 \\
10. & Kalium (K) & $\%$ & \\
\hline
\end{tabular}

Kandungan unsur pupuk organik cair dari kulit buah pisang dianalisis di Laboratorium Chem-Mix Pratama Banguntapan, Bantul, Yogyakarta. Unsur yang dianalisis meliputi unsur C, N, P, dan K. Fungsi utama unsur C yakni sebagai komponen utama senyawa-senyawa organik tumbuhan (Campbell dan Jane, 2008). Menurut Lingga dan Marsono (2002), fungsi utama $\mathrm{N}$ adalah berperan bagi tanaman untuk merangsang pertumbuhan secara keseluruhan, khususnya batang, cabang, dan daun. Unsur P berfungsi untuk merangsang pertumbuhan akar, khususnya akar benih dan tanaman muda. Peranan utama $\mathrm{K}$ adalah membantu pembentukan protein dan karbohidrat.

Hasil analisis kandungan unsur hara yang telah dilakakukan (Tabel 1.) menunjukkan bahwa pupuk organik cair dari kulit buah pisang kepok (Musa paradisiaca L. var. balbisina colla.) mengandung unsur $\mathrm{C}, \mathrm{N}, \mathrm{P}$, dan K. Pupuk organik cair tersebut diaplikasikan ke tanaman agar dapat diketahui pengaruhnya terhadap pertumbuhan tanaman. Tanaman yang diamati pertumbuhannya yakni tanaman bayam hijau (Amaranthus gracilis Desf). Tanaman akan memberi respon berupa pertambahan ukuran. Pertumbuhan tanaman yang diamati dan diukur meliputi panjang daun dan lebar daun, tinggi batang, berat basah, berat kering, serta kadar klorofil. Hasil yang diperoleh pada Tabel 2.

Tabel 2. Hasil Pengukuran Pertumbuhan Tanaman Bayam Hijau Umur 4 MST

\begin{tabular}{ccccccc}
\hline No. & P & PD (cm) & LD (cm) & TB (cm) & BB (gram) & $\begin{array}{c}\text { BK } \\
\text { (gram) }\end{array}$ \\
\hline 1. & P0 & $5,02^{\mathrm{b}}$ & $3,73^{\mathrm{b}}$ & 49,74 & 35,21 & 2,97 \\
2. & P1 & $4,53^{\mathrm{b}}$ & $3,66^{\mathrm{b}}$ & 51,24 & 34,12 & 3,12 \\
3. & P2 & $4,23^{\mathrm{b}}$ & $2,93^{\mathrm{b}}$ & 43,20 & 23,84 & 2,39 \\
4. & P3 & $4,53^{\mathrm{b}}$ & $3,23^{\mathrm{b}}$ & 46,58 & 27,66 & 2,55 \\
5. & P4 & $5,23^{\mathrm{b}}$ & $3,47^{\mathrm{b}}$ & 50,84 & 29,33 & 2,57 \\
\hline
\end{tabular}




\begin{tabular}{lllllll}
\hline 6. & P5 & $2,58^{\mathrm{a}}$ & $1,99^{\mathrm{a}}$ & 41,46 & 19,09 & 1,82 \\
\hline
\end{tabular}

Keterangan:

- Angka-angka yang tidak diberi notasi huruf, tidak berpengaruh nyata berdasarkan Uji ANAVA pada taraf $5 \%$

- Angka-angka yang ditandai oleh huruf yang sama setiap kolom tidak berbeda nyata berdasarkan Uji DMRT pada taraf $5 \%$
$\mathrm{P}$ : Perlakuan
P0 : konsentrasi $0 \mathrm{~mL} / \mathrm{L}$ (kontrol)
PD : Panjang Daun
$\mathrm{P} 1$ : konsentrasi $10 \mathrm{~mL} / \mathrm{L}$
LD : Lebar Daun
$\mathrm{P} 2$ : konsentrasi $20 \mathrm{~mL} / \mathrm{L}$
TB : Tinggi Batang
P3 : konsentrasi $30 \mathrm{~mL} / \mathrm{L}$
BB : Berat Basah
$\mathrm{P} 4$ : konsentrasi $40 \mathrm{~mL} / \mathrm{L}$
BK : Berat Kering
P5 : konsentrasi $50 \mathrm{~mL} / \mathrm{L}$

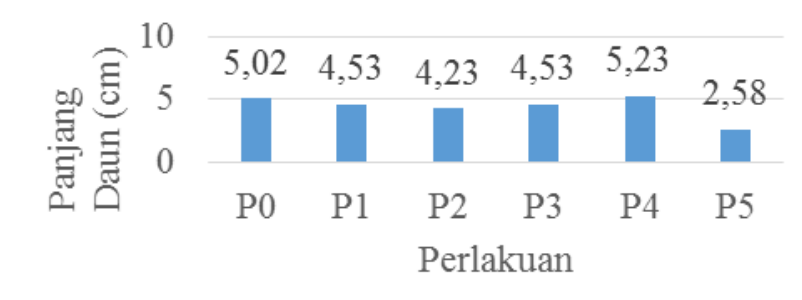

(a)

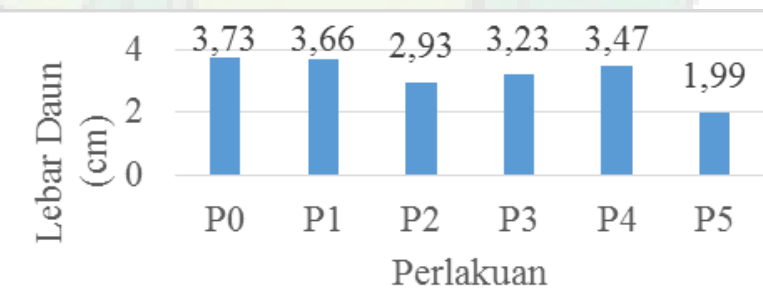

(b)

Gambar 1. Diagram batang perbandingan daun tanaman bayam hijau umur

4 MST (Amaranthus gracilis Desf) (a) panjang daun (b) lebar daun

\section{Keterangan}

$\mathrm{P} 0$ : konsentrasi $0 \mathrm{~mL} / \mathrm{L} \quad \mathrm{P} 3$ : konsentrasi $30 \mathrm{~mL} / \mathrm{L}$

$\mathrm{P} 1$ : konsentrasi $10 \mathrm{~mL} / \mathrm{L} \quad \mathrm{P} 4$ : konsentrasi $40 \mathrm{~mL} / \mathrm{L}$

$\mathrm{P} 2$ : konsentrasi $20 \mathrm{~mL} / \mathrm{L} \quad \mathrm{P} 5$ : konsentrasi $50 \mathrm{~mL} / \mathrm{L}$

Hasil uji DMRT (Tabel 2.) dan diagram batang (Gambar 1.) menunjukkan bahwa tidak terdapat beda nyata antara perlakuan P0, P1, P2, P3, dan P4. Rerata panjang daun dan lebar 
daun yang optimal adalah P1 (konsentrasi $10 \mathrm{~mL} / \mathrm{L}$ ), karena dengan pemberian konsentrasi $10 \mathrm{~mL} / \mathrm{L}$ telah dapat memacu pertambahan rerata panjang daun tidak berbeda signifikan dengan pemberian konsentrasi $20 \mathrm{~mL} / \mathrm{L}, 30 \mathrm{~mL} / \mathrm{L}$, maupun $40 \mathrm{~mL} / \mathrm{L}$. Kandungan unsur yang mempengaruhi panjang dan lebar daun yakni unsur nitrogen $(\mathrm{N})$ yang terdapat pada kulit buah pisang kepok (Tabel 1.). Nitrogen yang terdapat dalam pupuk organik kulit buah pisang berpengaruh terhadap pembentukan klorofil. Menurut Irawan (2016), nitrogen berperan dalam pembentukan protoplasma tanaman, terutama menyusun komponen protein dan klorofil. Unsur $\mathrm{N}$ dapat membantu proses fotosintesis sehingga dihasilkan fotosintat yang dapat ditranslokasikan serta disimpan untuk cadangan makanan. Fotosintat tersebut akan dirombak melalui proses respirasi, sehingga dihasilkan energi agar terjadi perbesaran sel dan pembelahan sel. Perbesaran dan pembelahan sel yang terjadi di daun membuat ukuran daun bertambah yakni panjang dan lebar daun.

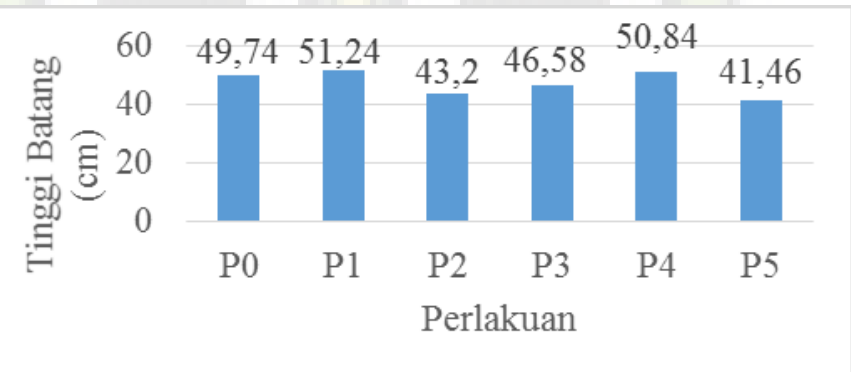

Gambar 2. Diagram batang perbandingan tinggi batang tanaman bayam hijau umur 4 MST (Amaranthus gracilis Desf)

Tinggi batang tanaman sebagai parameter untuk mengetahui pengaruh pemberian pupuk organik cair dari limbah buah kulit pisang kepok (Musa paradisiaca L. var. balbisina colla.) karena tinggi batang dapat memberikan respon yang relatif cepat pada perlakuan yang diberikan. Berdasarkan hasil uji ANAVA (Tabel 2.) tidak terdapat pengaruh nyata antar perlakuan P0, P1, P2, P3, P4, dan P5 hal ini disebabkan karena nitrogen (N) ditranslokasikan ke organ daun. Menurut (Devlin 1977 dalam Sauwibi 2011), pemupukan N tidak berpengaruh terhadap tinggi tanaman dikarenakan unsur $\mathrm{N}$ sebagai pembentuk klorofil lebih banyak dipusatkan ke ukuran daun. Rerata tinggi batang tanaman bayam hijau (Amaranthus gracilis Desf) yang optimal berdasarkan grafik (Gambar 2.) adalah P1 (konsentrasi $10 \mathrm{~mL} / \mathrm{L}$ ), karena dapat memicu terjadinya pembelahan sel meristem apikal. Walaupun tidak berpengaruh nyata nitrogen dapat memacu pertumbuhan ukuran batang tanaman bayam hijau. Unsur nitrogen mempengaruhi pertumbuhan tinggi tanaman. Hakim dkk (1986 dalam Haryadi dkk 2015) menjelaskan bahwa pertumbuhan tinggi terjadi disebabkan oleh pembelahan dan 
perpanjangan sel yang terdapat pada ujung pucuk tanaman. Proses terebut adalah bagian dari sintesis protein, tanaman memperoleh bahan organik dari tanah.

Selain unsur $\mathrm{N}$ yang berpengaruh terhadap pertumbuhan batang adalah unsur karbon (C). Unsur C merupakan struktur penyusun selulosa dan hemiselulosa yang merupakan struktural dinding sel. Menurut Bahri (2015), selulosa adalah senyawa polisakarida dengan rumus empiris $\left(\mathrm{C}_{6} \mathrm{H}_{10} \mathrm{O}_{5}\right)_{n}$. Unsur penguat utama dinding sel tumbuhan adalah suatu jaringan yang terdiri dari beberapa lapis serat selulosa. Selulosa di dalam dinding sel tumbuhan disertai oleh sejumlah besar polisakarida kompleks yang disebut dengan hemiselulosa.

Berat basah merupakan jumlah kandungan air di tanah yang diserap oleh tumbuhan. Rerata berat basah tertinggi berdasarkan Tabel 2. yakni perlakuan P1 (konsentrasi $10 \mathrm{~mL} / \mathrm{L}$ ), karena pada parameter panjang daun, lebar daun, dan tinggi batang P1 merupakan parameter dengan pertumbuhan yang paling optimal. Hal tersebut sesuai dengan pernyataan Haryadi (2015), bahwa berat basah tanaman menunjukkan unsur hara dan air yang diserap tanaman melalui akar, sehingga mempengaruhi pertumbuhan misalnya tinggi, jumlah daun dan luas daun. Berat segar tanaman adalah akumulasi dari parameter tersebut.

Unsur yang mempengaruhi penyerapan tanaman yakni kalium (K). Menurut Ohshiro dkk (2016), menyatakan bahwa kalium memiliki peran untuk meningkatkan penyerapan pada tanaman. Jasim (2016), menjelaskan bahwa peran kalium dalam penyerapan air oleh akar tanaman yaitu dengan cara mengatur pergerakan air dari sel akar ke jaringan xilem. Awalnya unsur $\mathrm{K}^{+}$yang diakumulasikan di dalam sitoplasma dan vakuola sel-sel parenkim akar bergerak menuju pembuluh xilem melalui plasmodesmata. Sel-sel akar hingga bagian luar yaitu sel epidermis mengalami degradasi potensial air yang diakibatkan oleh menurunnya potensial air dalam pembuluh xilem. Apabila potensial air dalam sel akar lebih rendah dari potensial air pada larutan tanah, maka akar tanaman dapat menyerap air sehingga meningkatkan potensial air di daun.

Rerata berat basah pada perlakuan P0 (konsentrasi $0 \mathrm{~mL} / \mathrm{L}$ ) lebih tinggi daripada rerata berat basah P1 (konsentrasi $10 \mathrm{~mL} / \mathrm{L}$ ) (Tabel 2.), tetapi berdasarkan hasil rerata berat kering menunjukkan P0 lebih rendah dibandingkan rerata berat P1. Hal ini disebabkan pada P0 hanya mengandung air sehingga berat basah yang dihasilkan paling tinggi, sedangkan berat kering mencerminkan berat tanaman setelah dikeringkan dan menyisakan hasil fotosintat dalam tanaman. Perlakuan P0 tidak diberikan pupuk organik cair sehingga unsur hara atau fotosintat yang dihasilkan lebih sedikit daripada P1 yang diberikan pupuk organik cair. Hasil analisis uji ANAVA (Tabel 2.) menunjukkan bahwa tidak terdapat perbedaan nyata terhadap 
pemberian pupuk organik cair kulit pisang kepok (Musa paradisiaca L. var. balbisina colla.) terhadap berat kering tanaman bayam hijau (Amaranthus gracilis Desf).

Klorofil berfungsi sebagai pigmen penyerap cahaya, sehingga dapat terjadi proses fotosintesis. Klorofil a dan b merupakan pigmen utama, klorofil a berperan lebih dominan daripada klorofil $\mathrm{b}$, karena klorofil a terdapat dalam 2 macam pusat reaksi yakni fotosistem I dan II. Lakitan (2018), menyatakan bahwa fotosistem I dan fotosistem II mengandung klorofil a dan sedikit klorofil b.

Tabel 3. Hasil uji klorofil daun bayam hijau (Amaranthus gracilis Desf) umur 4 MST

\begin{tabular}{cccc}
\hline Perlakuan & $\begin{array}{c}\text { Klorofil a } \\
(\mathbf{m g} / \mathbf{L})\end{array}$ & $\begin{array}{c}\text { Klorofil b } \\
(\mathbf{m g} / \mathbf{L})\end{array}$ & $\begin{array}{c}\text { Klorofil Total } \\
(\mathbf{m g} / \mathbf{L})\end{array}$ \\
\hline P0 (kontrol) & $4,15 \times 10^{-3}$ & $1,27 \times 10^{-3}$ & $4,61 \times 10^{-3}$ \\
P1 & $5,32 \times 10^{-3}$ & $2,17 \times 10^{-3}$ & $6,31 \times 10^{-3}$ \\
P2 & $5,09 \times 10^{-3}$ & $5,09 \times 10^{-3}$ & $5,65 \times 10^{-3}$ \\
P3 & $5,25 \times 10^{-3}$ & $3,51 \times 10^{-3}$ & $7,08 \times 10^{-3}$ \\
P4 & $6,18 \times 10^{-3}$ & $2,83 \times 10^{-3}$ & $7,48 \times 10^{-3}$ \\
P5 & $7,18 \times 10^{-3}$ & $4,84 \times 10^{-3}$ & $9,71 \times 10^{-3}$ \\
\hline
\end{tabular}

Hasil rata-rata uji klorofil (Tabel 3.) menunjukkan bahwa rata-rata kadar klorofil tertinggi terdapat pada perlakuan P5. Pembentukan klorofil dipengaruhi oleh keberadaan nitrogen (N), hal ini sejalan dengan Mashud (2007), klorfil a dengan struktur kimia $\mathrm{C}_{55} \mathrm{H}_{72} \mathrm{O}_{5} \mathrm{~N}_{4} \mathrm{Mg}$ dan klorofil b dengan struktur kimia $\mathrm{C}_{55} \mathrm{H}_{70} \mathrm{O}_{6} \mathrm{~N}_{4} \mathrm{Mg}$, sehingga keberadaan nitrogen sangat dibutuhkan karena penyusun dalam struktur klorofil. Menurut Suharja dan Sutarno (2009), nitrogen yang diserap oleh tumbuhan berbentuk ammonia dan selanjutnya ammonia mengalami perubahan menjadi asam glutamat, dikatalisis oleh enzim glutamine sintase. Fungsi asam glutamat yakni sebagai bahan dasar biosintesis asam amino dan asam nukleat. Pembentukan klorofil membutuhkan asam glutamat sebagai prekusor cincin porfirin.

Faktor yang mempengaruhi pertumbuhan tanaman terbagi menjadi dua yakni faktor internal dan eksternal. Faktor eksternal salah satunya adalah faktor lingkungan. Pertumbuhan dan hasil produksi juga dipengaruhi oleh kelembapan udara. Faktor lingkungan diamati satu minggu sekali pada pagi hari. Suhu lingkungan pada tempat penelitian rata-rata adalah 34,6 ${ }^{0} \mathrm{C}$ dan kelembapan antara $69,9 \%$. Tumbuhan memiliki suhu maksimum dan minimum yang berbeda untuk dapat bertahan hidup. Menurut Merlina (2016), jika suhu terlalu rendah atau terlalu tinggi dapat mengakibatkan terganggunya laju pertumbuhan tanaman bayam hijau. Suhu optimal tanaman bayam hijau berkisar antara $20^{\circ} \mathrm{C}-30^{\circ} \mathrm{C}$, Hadisoeganda (1996) menambahkan bahwa tanaman bayam hijau memiliki kemampuan untuk beradaptasi tinggi. Oleh karena itu, bayam hijau dapat beradaptasi pada suhu $34,6{ }^{\circ} \mathrm{C}$. 
Kelembapan udara yang optimal untuk membudidayakan tanaman bayam hijau yaitu di atas 60\% (Rukmana, 2010). Hal ini menunjukkan kelembapan lingkungan saat penelitian cukup optimum untuk tanaman bayam hijau. Suhu dan kelembapan mempengaruhi proses transpirasi pada tanaman. Proses transpirasi tanaman melalui stomata yakni mulut daun yang berfungsi sebagai jalan keluar masuknya $\mathrm{CO}_{2}, \mathrm{H}_{2} \mathrm{O}$, dan $\mathrm{O}_{2}$. Buka tutup stomata dipengaruhi oleh unsur kalium (K).

\section{SIMPULAN}

Pemberian pupuk organik cair dari kulit buah pisang kepok (Musa paradisiaca L. var. Balbisina colla.) memberi pengaruh baik terhadap pertumbuhan tanaman bayam hijau (Amaranthus gracilis Desf). Konsentrasi POC yang dapat meningkatkan panjang dan lebar daun tanaman bayam hijau (Amaranthus gracilis Desf) adalah 10 mL/L (P1) dan konsentrasi yang dapat meningkatkan kadar klorofil tanaman bayam adalah 50 mL/L (P5).

\section{REFERENSI}

Badan Pusat Statistik. 2017. Statistik Tanaman Sayuran dan Buah-buahan Semusim Indonesia. Jakarta: Badan Pusat Statistik.

Bahri, Syamsul. 2015. Pembuatan Pulp dari Batang Pisang. Jurnal Teknologi Kimia Unimal, 4 (2): 36-50.

Campbell, N. A. dan Jane B. Reece. 2008. Biologi Edisi Kedelapan Jilid 1. Jakarta: Erlangga.

Dwicaksono, M. R. B., Bambang S. dan Liliya D. S. 2014. Pengaruh Penambahan Effective Microorganisms pada Limbah Cair Perikanan terhadap Kualitas Pupuk Organik Cair. Jurnal Sumber Daya Alam dan Lingkungan, 1 (1): 7-11.

Gani, Anischan. 2013. Bagan Warna Daun (BWD). Balai Besar Penelitian Tanaman Padi.

Hadisoeganda, A. W. W. 1996. Bayam Hijau Sayuran Penyangga Petani di Indonesia. Bandung: Balai Penelitian Tanaman Sayuran.

Haryadi, D., Husna Y. dan Sri Y. 2015. Pengaruh Pemberian Beberapa Jenis Pupuk Terhadap Pertumbuhan dan Produksi Tanaman Kailan (Brassica alboglabra L.). JOM FAPERTA, 2 (2):

Handayani, S. H., Ahmad Yunus, dan Ari Susilowati. 2015. Uji Kualitas Pupuk Organik Cair dari berbagai Macam Mikroorganisme Lokal (MOL). El-Vivo, 3 (1): 54-60.

Indriani, Yovita Hety. 2007. Membuat Kompos secara Kilat. Jakarta: Penebar Swadaya.

Irawan, L., Armaini dan Fetmi S. 2016. Aplikasi Limbah Cair Biogas dan Pupuk Nitrogen pada Tanaman Pakchoy (Brassica chinensis L.). JOM FAPERTA, 3 (1): 1-11.

Jasim. 2016. Pengaruh Pemupukan Kalium terhadap Kelakuan Stomata dan Ketahanan Kekeringan. Jurnal Agrotek Lestari, 2 (2): 47-54.

Lakitan, Benyamin. 2018. Dasar-dasar Fisiologi Tumbuhan. Depok: Raja Grafindo Persada. Lingga, Pinus dan Marsono. 2002. Petunjuk Penggunaan Pupuk. Jakarta: Penebar Swadaya. 
Mashud, Nurhaini. 2007. Stomata dan Klorofil dalam Hubungannya dengan Produksi Kelapa. Buletin Palama (32): 52-59

Merlina, Alvi. 2016. Investasi Emas Hijau dari Budidaya Bayam Hijau. Depok: Villam Media.

Oshiro, Masanobu, Md. Amzad H., Ichiro N. Hikaro A., Masanobu T., Prasanta Chitta B., dan Akihiro N. 2016. Effect of Soil Types and Fertilizer on Growth, Yield, and Quality of Edible Amaranthus tricolor Lines in Okinawa, Japan. Plant Production Science, 19 (1): 61-72.

Paradosi, Andri H., Irianto, dan Mukhsin. 2014. Respon Tanaman Sawi terhadap Pupuk Organik Cair Limbah Sayuran pada Lahan Kering UltisoL. Var. Balbisina colla. Prosiding Seminar Nasional Lahan Suboptimal, Palembang: 26-27.

Rahmawati, Lina, Salfina, dan Elita Agustina. 2017. Pengaruh Pupuk Organik Cair Kulit Pisang terhadap Pertumbuhan Selada (Lactuca sativa). Prosiding Seminar Nasional Biotik 2017 ISBN: 978-602-60401-3-8. 296-301.

Rambitan, V. M. M. dan Mirna Sari P., 2013. Pengaruh Pupuk Kompos Kulit Pisang Kepok (Musa paradisiaca L.) terhadap Pertumbuhan dan Hasil Tanaman Kacang Tanah (Arachis hypogea L.) sebagai Penunjang Praktikum Fisiologi Tumbuhan. Jurnal EduBio Tropika, 1 (1): 14-24.

Rohmah, Yuliawati. 2016. Outlook Komoditas Pertanian Sub Sektor Holtikultura: Pisang. Jakarta: Pusat Data dan Sistem Informasi Pertanian Kementrian Pertanian.

Rukmana, Rahmat. 2010. Bayam hijau. Yogyakarta: Kanisius.

Salissbury, Frank B. dan Ross, Cleon W. 1995. Fisiologi Tumbuhan Jilid 1. Bandung: ITB Press.

Sauwibi, D. A., M. Muryono dan F. Hendrayana. 2011. Pengaruh Pupuk Organik Nitrogen terhadap Pertumbuhan dan Produktivitas Tembakau (Nicotiana tabacum L.) Varietas Prancak pada Kepadatan Populasi 45.000/Ha di Kabupaten Pamekasan, Jawa Timur. ITS Repsitory (Paper). Surabaya.

Suharja dan Sutarno. 2009. Biomass, Chlorophyll and Nitrogen Content of Leaves of Two Chili Pepper Varieties (Capsicum annum) in Different Fertilization Treatments. Nusantara Bioscience 1: 9-16.

Wahyuningsih dan Edy Supriyo. 2013. Teknologi Produksi Pupuk Organik Cair dari Limbah Sampah Rumah Tangga di Kelurahan Lempongsari, Kodya Semarang dengan Komposer EM-4. METANA, 9 (1): 23-27. 